4. Regan, D. Evoked potentials: recording methods [Text] / D. Regan, M. P. Regan // Encyclopedia of Neuroscience. 2009. - P. 29-37. doi: 10.1016/b978-008045046-9.00317-x

5. Шугуров, О. О. Викликані потенціали спинного мозку при дії на нього механічних подразнень [Текст] / О.О.Шугуров // Вісник Дніпропетровського університету. Біологія. Медицина. - 2011. - № 2. - С. 125-129.

6. Шугуров, О. А. Вызванные потенциалы спинного мозга [Текст] / О. А. Шугуров, О. О. Шугуров. - Днепропетровск: Наука и образование, 2006. - 319 с.

7. Шугуров, О. О. Идентификация повреждений дорсальных корешков по характеру продольного распределения вызванных потенциалов спинного мозга [Текст] / О. О. Шугуров // ScienceRise. - 2016. - Т. 2, № 1 (19). - C. 16-22. doi: $10.15587 / 2313-8416.2016 .60275$

8. Quiroz-Gonzalez, S. Cord dorsum potentials evoked by electroacupuncture applied to the hind limbs of rats [Text] / S. Quiroz-Gonzalez, B. Segura-Alegria, J. C. Guadarrama-Olmos, I. Jimenez-Estrada // Journal of Acupuncture and Meridian Studies. - 2014. - Vol. 7, Issue 1. - P. 25-32. doi: 10.1016/j.jams.2013.06.013

9. Grunewald, B. Measuring spinal presynaptic inhibition in mice by dorsal root potential recording in vivo [Text] / B. Grunewald, C. Geis // Journal of Visualized Experiments. - 2014. - Vol. 85. - P. e51473. doi: 10.3791/51473

10. Carlton, S. M. Nociceptive primary afferents: they have a mind of their own [Text] / S. M. Carlton // The Journal of Physiology. - 2014. - Vol. 592, Issue 16. - P. 3403-3411. doi: 10.1113/jphysiol.2013.269654

11. Cote, M.-P. Plasticity in ascending long propriospinal and descending supraspinal pathways in chronic cervical spinal cord injured rats [Text] / M.-P. Cote, M. R. Detloff, R. E. Wade, M. A. Lemay, J. D. Houle // Frontiers in Physiology. - 2012. Vol. 3. - P. 330. doi: 10.3389/fphys.2012.00330

12. Wang, G. Development of "normal" dermatomes and somatotopic maps by "abnormal" populations of cutaneous neurons [Text] / G. Wang, S. A. Scott // Developmental Biology. - 2002. - Vol. 251, Issue 2. - P. 424-433. doi: 10.1006/dbio.2002.0824

13. Laumonnerie, C. Commissural axonal corridors instruct neuronal migration in the mouse spinal cord [Text] / C. Laumonnerie, Y. G. Tong, H. Alstermark, S. I. Wilson // Nature Communications. - 2015. - Vol. 6. - P. 7028. doi: 10.1038/ncomms8028

14. Rudomin, P. In search of lost presynaptic inhibition [Text] / P. Rudomin // Experimental Brain Research. - 2009. Vol. 196, Issue 1. - P. 139-151. doi: 10.1007/s00221-009-1758-9

Дата надходження рукопису 18.01.2017

Шугуров Олег Олегович, доктор биологических наук, профессор, кафедра общей биологии и водных биоресурсов, Днепропетровский национальный университет им. Олеся Гончара, пр. Гагарина, 72, г. Днепр, Украина, 49010

E-mail: shugu@yandex.ru

УДК 575.224.4:504.5:633.11

DOI: $10.15587 / 2519-8025.2017 .93799$

\title{
THE ANALYSIS OF MUTATION VARIABILITY OF WINTER WHEAT UNDER SOIL CONTAMINATION WITH HEAVY METALS OF INDUSTRIAL DISCHARGES
}

\author{
(C) R. Yakymchuk, S. Sorokina
}

Вивчено на прикладі озимої пшенищі генетичні наслідки забруднення важкими металами територій
впливу викидів промислових підприємств. Частота видимих мутацій перевищує контрольні показники в
2,1-4,9 рази. Типовий спектр їх типів - пізньостиглість, високо- і низькорослість, довгий, щільний, нещі-
льний колос, може бути використаний як індикатор забруднення навколишнього середовища важкими
металами

Ключові слова: Triticum аеstivum, мутаційна мінливість, важкі метали, мутації, мутагени, генетичні наслідки

\section{Introduction}

The ecological situation in Ukraine is characterized with considerable anthropogenic loads of the environment in the form of mutagens of physical and chemical nature. Total contamination of air, soil, drinking water and foodstuffs with xenobiotic substances resulted in genetically explained pathology, which can be seen in inborn defects of the development, cytogenetic disorders in germinal and somatic cells [1]. The situation is particularly dangerous in the areas of intensive industrial production - Zaporizhia, Dnipropetrovsk, Donetsk, IvanoFrankivsk, Luhansk and Kharkiv regions, where discharges of industrial businesses amount to $8 \%$ of contaminating substances of the country, and discharges per person are $140.2 \mathrm{~kg}$ [2]. A large share of them belongs to heavy metal ions which enter the atmosphere as spray and remain in large amounts in the soil; the latter proves the main tendencies in long-term contamination processes $[3,4]$. To prevent negative biological consequences of the industrial effect on the environment, it is expedient to make mutagen estimation of soil surface with the possibility to further predict inherited changes in the generations to come $[5,6]$.

\section{Literature review}

One of the pre-conditions of the analysis and prediction of the contamination level in industrial centers is a thorough control over the concentration of heavy metal ions, as the most toxic and aggressive contaminating substances [7]. Their entry into the plants is accompanied by 
the damage of ultra structure and functioning of cell organels, changes in cell metabolism, growth and development depression, productivity decrease. One of the main mechanisms of heavy metal toxic effect is their interaction with $\mathrm{SH}$-groups of proteins, which leads to the change of macromolecule conformation, enzyme inactivation, damage of membrane structure as well as tylakoidal membranes of chloroplasts, and this can be the reason for expression deregulation of chloroplast genes, and as a result, the decrease of rate of photosynthesis [8-13]. In addition to direct toxic effect of heavy metals, occurrence of physiological and functional and morphological anomalies, increase of general disease incidence, there are some remote impacts which concern the major functions of living systems - reproduction and productivity, generative characteristics and mortality.

Most of the researches were aimed at studying the level of heavy metal accumulation in the soil, water reservoirs and plants depending on the distance from a contamination source [14]. There are also a number of facts which prove the toxic effect of some ingredients of environmental contamination on cytogenetic and biochemical systems of cultured plants in the process of ontogenesis. They helped confirm the availability of high induction frequency of synergic and antagonistic effects in the conditions of mutual influence of low concentrations of lead and cadmium on plants, and the fact that these effects determine the occurrence of genetic disorders in the studied area. In most investigations mutagen activity of double effect of heavy metals on the plants is studied [15], whereas triple and multiple effect has not been studied.

In the monitoring system of environmental mutagens, genetic researches take an important place; they make it possible to estimate the consequences of the joint effect of low concentrations of heavy metal ions on plants on cell and molecular levels in natural conditions for the present-day generation and for the generations to come $[1,15,16]$. To do monitoring of real environmental contamination with genetically dangerous compounds, plant test-systems, soft wheat (T. aestivum $L$.) is included, suit the best $[17,18]$.

With this in view, it is expedient to study genetic consequences of environmental contamination with heavy metals of industrial discharges from the point of view of the disorders of generative functions of genetic apparatus, induced by these effects, and to register a visible mutation level in several successive generations.

\section{Aim and research problems}

The purpose of the research was to study genetic consequences of soil contamination with heavy metals in the zones of industrial discharges according to frequency and spectrum of visible mutations of winter wheat.

To reach this goal, the following tasks were implemented:

- The record of winter wheat mutations in generations $\mathrm{M}_{2}-\mathrm{M}_{3}$, which were affected by regular effect of soil contamination with heavy metals in the area of industrial discharges, was kept;

- Frequency and spectrum of mutant types, when plants of generation $\mathrm{M}_{1}$ were grown on the plots contaminated with heavy metals, were studied;
- Spectrum of winter wheat mutations, which could be used as typical indicators of industrial soil contamination with heavy metals, was identified.

\section{Materials and methods}

To study mutagenic activity of soil contamination with heavy metals of industrial discharges, in 2012-2013 winter wheat varieties Al'batros odes'kyi and Zymoiarka were grown $5 \mathrm{~km}$ from Burshtynska TPS on the axis of air mass flow, within the industrial areas of SC (stock company) "Poltavchimmash", SPC (state-run production company) "Specialized company for thermal processing of firm household garbage" in Kharkiv city, SJC (stock joint company) "Luhansk accumulator producing company", UC (utility company) "Lubny water supply station" and near B. Khmelnytskyi Street in Kostiantynivka. The analysis to determine heavy metal content in soil samples was made in the department of agro-ecology and analytical research at NSC "Institute of Agriculture of NAAS" using the methods which correspond to the legislative enactments of Ukraine. The concentration of lead mobile forms in the areas adjacent to Burshtynska TPS was 1.5 CPC (critical permissible concentration). The content of zinc and lead in the soil of the industrial zone of SC "Poltavchimmash" exceeded CPC by 40.9 and 12.8 times, correspondingly; that of cadmium in the industrial zone of SPC "Specialized company for thermal processing of firm household garbage" in Kharkiv city - by 13 times; the content of cadmium, lead, copper, nickel, zinc in the soil near SJC "Luhansk accumulator producing company" - by 13.0, 5.5, 5.8, 4.4, 5.6 times, correspondingly; cadmium content in the soil near UC "Lubny water supply station" - by 9.8 times; that of zinc, lead and cadmium in the soil near B. Khmelnytskyi Street in Kostiantynivka - by 20.2, 17.0 and 10.5 times, correspondingly. The territory of the experimental farm of the Institute of Plant Physiology and Genetics of Ukraine's NAS (Hlevaha, Vasylkiv district, Kyiv rgn.), where spontaneous level of mutation variability of winter wheat had been studied for many years, was taken as the control.

The first plant generation $\left(\mathrm{M}_{1}\right)$ was grown by full sowing on the contaminated areas. The plants of generation $\mathrm{M}_{2}$ and $\mathrm{M}_{3}$ were grown in families which helped identify macro- and micro mutations and keep record of them. A family meant a group of plants received from seeds of one spike. Various cases of mutations were the plants which differed phenotypically from initial forms within one family. All families of the plants with changed signs were carefully examined during major stages of their growth and development. Frequency and spectrum of mutation forms of only generation $\mathrm{M}_{3}$ were recorded after checking the inheritance of changed signs as to the correlation of a number of families with mutant plants to the studied families of generation $\mathrm{M}_{2}$.

Mathematic data processing and correlation analysis were made using traditional methodology [19, 20]. The adequacy of the difference between averages of experimental variants and the control was estimated by the standard of Student and Fisher. Averages and their standard deviations are given in the tables. 


\section{Results of the research}

Regular effect of soil mutagens, in particular heavy metals, in the area adjacent to Burshtynska TPS, caused significant increase of a visible mutation level in generation $\mathrm{M}_{2}-\mathrm{M}_{3}$ of Al'batros odes'kyi winter wheat. Mutation frequency exceeded spontaneous indicators by 3.9 times, and was $3.89 \pm 0.44 \%$ (Table 1 ).

The increased level of mutation variability of winter wheat was recorded on the contaminated soil in the areas of other industrial companies. Increased content of lead and zinc ions in the soil near SC "Poltavchimmash" caused the increase of mutation frequency of varieties Al'batros odes'kyi and Zymoiarka up to 3,93 $\pm 1,11 \%$ and $1,63 \pm 0,81 \%$, which was more than the control by 4.9 and 2.1 times, respectively. The increased content of heavy metals in the soil near B. Khmelnytskyi Street in Kostiantynivka, in the industrial zone of SPC "Specialized company for thermal processing of firm household garbage" Kharkiv city, in the area of SJC "Luhansk accumulator producing company", near UC "Lubny water supply station" can explain the induction in plants $\mathrm{M}_{2}-\mathrm{M}_{3}$ variety Zymoiarka $3.18 \pm 0.87 \%, 2.42 \pm 0.69 \%, 2.20 \pm$ $\pm 0.66 \%, 2.65 \pm 0.76 \%$ of mutant families, which is higher than spontaneous level indicators by 2.9-4.1 times. Analyzing mutation frequency of winter wheat, grown on the soils contaminated with industrial discharges, one can assume that its level is determined by both the concentration and the spectrum of heavy metal ions. Winter wheat grown near B. Khmelnytskyi Street in Kostiantynivka appeared to have the highest level of visible mutations $-3.18 \pm 0.87 \%$, where the most intensive contamination with three heavy metals - zinc, lead and cadmium - was recorded. Heavy metal scattering in the city itself is connected with the operation of "Ukrzinc" which results in reasonable and very dangerous contamination levels of its district [21]. A significant increase of the mutation variability level of the plants grown near UC "Lubny water supply station", SPC "Specialized company for thermal processing of firm household garbage", SJC "Luhansk accumulator producing company" can be associated with the increased concentration of cadmium ions in the soil.

Table 1

Frequency of visible mutations $\left(\mathrm{M}_{2}-\mathrm{M}_{3}\right)$ of winter wheat when the soil is contaminated with heavy metals of industrial discharges (2012-2013)

\begin{tabular}{|l|c|c|c|}
\hline \multicolumn{1}{|c|}{ Effect variant } & $\begin{array}{c}\text { No of studied } \\
\text { families, pieces }\end{array}$ & $\begin{array}{c}\text { No of mutant } \\
\text { families, pieces }\end{array}$ & $\begin{array}{c}\text { Frequency of mutant } \\
\text { families, } \%\end{array}$ \\
\hline \multicolumn{3}{|c|}{ Al'batros odes'kyi } \\
\hline Hlevaha (control) & 506 & 5 & $0,99 \pm 0,45$ \\
\hline 5 km from Burshtynska TPS & 514 & 20 & $3,89 \pm 0,44^{*}$ \\
\hline Hlevaha (control) & 494 & 4 & $0,81 \pm 0,40$ \\
\hline SC "Poltavchimmash" & 305 & 12 & $3,93 \pm 1,11^{*}$ \\
\hline \multicolumn{2}{|c|}{ Zymoiarka } & 4 & $0,77 \pm 0,38$ \\
\hline Hlevaha (control) & 522 & 4 & $1,63 \pm 0,81$ \\
\hline SC "Poltavchimmash" & 245 & 13 & $3,18 \pm 0,87^{*}$ \\
\hline B. Khmelnytskyi Street in Kostiantynivka & 408 & 12 & $2,42 \pm 0,69^{*}$ \\
\hline $\begin{array}{l}\text { SPC "Specialized company for thermal processing of } \\
\text { firm household garbage", of Kharkiv city }\end{array}$ & 495 & 11 & $2,20 \pm 0,66^{*}$ \\
\hline SJC "Luhansk accumulator producing company" & 501 & 12 & $2,65 \pm 0,76^{*}$ \\
\hline UC "Lubny water supply station" & 452 & & \\
\hline
\end{tabular}

Note: *-difference as to the control is statistically true at $P \leq 0,05$

High frequency of visible mutations of winter wheat, induced by soil contamination with heavy metals, was characterized with a wide spectrum of their types:

1) high-grown,

2) low-grown,

3) intensive growth,

4) early ripening,

5) average early,

6) late ripening,

7) long spike,

8) short spike,

9) dense spike,

10) loose spike,

11) cylindrical spike,

12) square-headed spike,

13) spelt spike,

14) twisted spike axis,

15) awned spike,

16) semi-awned spike,

17) awnless spike,
18) additional spikes,

19) antocyanin awn,

20) antocyanin spike husk,

21) wide leaf,

22) yellow peak of a flag leaf,

23) light-green leaf,

24) lack of wax film.

In the conditions taken as the control, spectrum, depending on plant genotype, contained 3-5 mutation types. The largest number of visible mutation types of winter wheat Al'batros odes'kyi was recorded under the effect of soil contamination with heavy metals on the territory adjacent to Burshtynska TPS (Table 2). Such mutations as high- and low-grown, dense, short and squareheaded spike were predominant (fig. 1). Their level statistically exceeded the control indicators $(0.00-0.40 \%)$ and ranged within $0.78-1.56 \%$. Mutation spectrum included a great deal of inherited changes, connected with structural spike changes: long, loose, cylindrical spike; 
the frequency was $0.20-0.58 \%$, whereas their frequency in the control was $0.00-0.20 \%$.

The occurrence of mutations according to the duration of vegetative period can be connected with the consequences of soil contamination near Burshtynska TPS; although they were not found under spontaneous mutagenesis in the control. Frequency of average early and late ripening forms was equal to $0.39 \%$ and $0.58 \%$, respectively. Awnless and semi-awned pike, intensive growth were seen among mutations with quite a low frequency $(0.20 \%)$. Original and rare mutations were found with the same frequency: wide leaf, yellow peak of a flag leaf. The induction of several mentioned mutations and the lack of the mentioned visible inherited changes in the control prove the fact of their occurrence under the effect of soil contamination with discharges of Burshtynska TPS. However, low frequency of the occurrence of original and rare mutations, their lack under the effect of soil contamination with discharges of other companies make it impossible to use them as universal indicators of environmental contamination with heavy metals.

The largest number of mutant types -14 - was recorded in winter wheat Zymoiarka grown on the territory of UC "Lubny water supply station" (Table 3). The smallest number of visible mutation types was induced in the conditions of a contaminated industrial zone of SC "Poltavchimmash". Spectrum of mutation types included a set of typical ones, which were found with high frequency in both varieties of winter wheat, affected by soil contamination with heavy metals of all studied objects.

Table 2

Spectrum of visible mutations of winter wheat $\left(\mathrm{M}_{2}-\mathrm{M}_{3}\right)$ variety Al'batros odes'kyi under the effect of the soil contamination with heavy metals of industrial discharges (2012-2013)

\begin{tabular}{|c|c|c|c|c|c|c|c|c|c|c|c|c|c|c|c|c|c|c|}
\hline \multirow{2}{*}{ Effect variant } & \multicolumn{18}{|c|}{ Mutation types, \% } \\
\hline & HG & LG & IG & ER & $\mathrm{AE}$ & LR & LS & SS & DS & LOS & $\mathrm{CS}$ & SHS & SAS & AS & AA & WL & YL & LL \\
\hline $\begin{array}{l}\text { Hlevaha } \\
\text { (control) }\end{array}$ & 0,40 & 0,40 & 0,00 & 0,00 & 0,00 & 0,00 & 0,20 & 0,40 & 0,20 & 0,00 & 0,00 & 0,00 & 0,00 & 0,00 & 0,00 & 0,00 & 0,00 & 0,00 \\
\hline $\begin{array}{c}5 \mathrm{~km} \text { from } \\
\text { Burshtynska } \\
\text { TPS }\end{array}$ & $1,17^{*}$ & 0,78 & 0,20 & 0,00 & 0,58 & 0,39 & 0,20 & 1,56 & 0,78 & 0,39 & 0,58 & $0,78^{*}$ & 0,20 & 0,20 & 0,00 & 0,20 & 0,20 & 0,00 \\
\hline $\begin{array}{l}\text { Hlevaha } \\
\text { (control) }\end{array}$ & 0,61 & 0,20 & 0,00 & 0,00 & 0,20 & 0,00 & 0,00 & 0,00 & 0,00 & 0,00 & 0,00 & 0,00 & 0,00 & 0,00 & 0,00 & 0,00 & 0,00 & 0,00 \\
\hline $\begin{array}{l}\text { SC «Poltav- } \\
\text { chimmash» }\end{array}$ & $2,30^{*}$ & 0,98 & $1,31^{*}$ & 0,66 & 0,00 & 0,98 & 0,98 & 0,33 & 0,33 & 0,33 & 0,00 & 0,33 & 0,00 & 0,00 & 0,33 & 0,00 & 0,00 & 0,33 \\
\hline
\end{tabular}

Note: $H G$ - high-grown, $L G$ - low-grown, IG - intensive growth, ER - early ripening, AE - average early, LR - late ripening, $L S$ - long spike, SS - short spike, DS - dense spike, LOS - loose spike, CS - cylindrical spike, SHS - square-headed spike, SAS - semi-awned spike, $A S$ - awnless spike, $A A$ - antocyanin awn, WL - wide leaf, $Y L$ - yellow peak of a flag leaf, LL-light-green leaf; * -difference as to the control is statistically true at $P \leq 0,05$

Table 3

Spe ctrum of visible mutations of winter wheat $\left(\mathrm{M}_{2}-\mathrm{M}_{3}\right)$ variety Zymoiarka under the effect of the soil contamination with heavy metals of industrial discharges (2012-2013)

\begin{tabular}{|c|c|c|c|c|c|c|c|c|c|c|c|c|c|c|c|c|c|c|c|}
\hline Effect variant & \multicolumn{19}{|c|}{ Mutation types, \% } \\
\hline & $\mathrm{HG}$ & LG & IG & $\mathrm{AE}$ & LR & LS & SS & DS & LOS & $\mathrm{CS}$ & SHS & SPS & TS & AS & SAS & ASS & $\mathrm{ASH}$ & YL & LW \\
\hline Hlevaha (control) & 0,19 & 0,00 & 0,19 & 0,19 & 0,00 & 0,19 & 0,00 & 0,00 & 0,00 & 0,00 & 0,00 & 0,00 & 0,00 & 0,00 & 0,19 & 0,00 & 0,00 & 0,00 & 0,00 \\
\hline $\begin{array}{l}\text { SC «Poltav- } \\
\text { chimmash» }\end{array}$ & 0,82 & 0,41 & 0,00 & 0,00 & 0,41 & 0,41 & 0,00 & 0,41 & 0,00 & 0,00 & 0,00 & 0,00 & 0,00 & 0,00 & 0,00 & 0,00 & 0,00 & 0,00 & 0,00 \\
\hline $\begin{array}{c}\text { B. Khmel- } \\
\text { nytskyi Str., } \\
\text { Kostiantynivka }\end{array}$ & 1,23 & 0,74 & 0,49 & 0,00 & $1,23 *$ & 0,74 & 0,00 & 0,25 & 0,25 & 0,00 & 0,00 & 0,25 & 0,00 & 0,25 & 0,25 & 0,00 & 0,00 & 0,00 & 0,00 \\
\hline $\begin{array}{l}\text { SPC "Specialized } \\
\text { company for } \\
\text { thermal pro- } \\
\text { cessing of firm } \\
\text { household gar- } \\
\text { bage", of Kharkiv } \\
\text { city }\end{array}$ & 1,21 & 0,40 & 0,00 & 0,61 & 0,40 & 0,00 & 0,20 & 0,20 & 0,20 & 0,00 & 0,00 & 0,00 & 0,00 & 0,00 & 0,40 & 0,00 & 0,00 & 0,00 & 0,00 \\
\hline $\begin{array}{l}\text { SJC "Luhansk ac- } \\
\text { cumulator pro- } \\
\text { ducing company" }\end{array}$ & 0,40 & 0,40 & 0,20 & 0,20 & 0,60 & 0,20 & 0,00 & 0,60 & 0,40 & 0,00 & 0,00 & 0,00 & 0,20 & 0,00 & 0,20 & 0,00 & 0,20 & 0,00 & 0,00 \\
\hline $\begin{array}{l}\text { UC "Lubny water } \\
\text { supply station" }\end{array}$ & 0,44 & $1,11 *$ & 0,00 & 0,22 & $1,11 *$ & 0,22 & 0,22 & 0,44 & 0,44 & 0,22 & 0,66 & 0,00 & 0,00 & 0,00 & 0,22 & 0,22 & 0,00 & 0,22 & 0,22 \\
\hline
\end{tabular}

Note: HG - high-grown, LG - low-grown, IG - intensive growth, AE - average early, LR - late ripening, LS - long spike, SS - short spike, DS - dense spike, LOS - loose spike, CS - cylindrical spike, SHS - square-headed spike, SPS - spelt spike, TS - twisted spike axis, AS awned spike, SAS - semi-awned spike, ASS - additional spikes, ASH - antocyanin spike husk, YL - yellow peak of a flag leaf, LW - lack of wax film; *-difference as to the control is statistically true at $P \leq 0,05$

Among them are late ripening, high- and lowgrown forms, long, dense, loose spike. Among the mutations there were the ones induced by soil contamination within the areas affected by discharges of some companies. Thus, plants of variety Al'batros odes'kyi showed a considerable increase of mutation frequency intensive growth $(1.31 \%)$ under the effect of soil contamination in the industrial zone of SC "Poltavchim- 
mash". These conditions became the induction factors with frequency $0.66 \%$ of early ripening forms. Plants of variety Zymoiarka had such mutation as semi-awned spike (fig. 2), which was connected with soil contamination with heavy metals and was fixed with frequency $0.20-0.40 \%$. Average early mutants of winter wheat Zymoiarka, whose frequency was $0.20-0.61 \%$, were recorded under the effect of soil contamination with heavy metals on the territory of SPC "Specialized company for thermal processing of frim household garbage" in Kharkiv city, SJC "Luhansk accumulator producing company" and UC "Lubny water supply station". Soil contamination of the territory of UC "Lubny water supply station" caused the occurrence of mutation squareheaded spike with frequency $0.66 \%$. Such mutations as antocyanin awns, light-green leaf with frequency $0.33 \%$ were seen on variety Al'batros odes'kyi, and variety Zymoiarka showed awned, short, cylindrical, spelt spike with frequency $0.20-0.25 \%$. Original types of induced mutations - spike with twisted axis, additional spikes, antocyanin spike husk, yellow peak of a flag leaf, lack of wax film - were typical for winter wheat samples grown on the territory of SJC "Luhansk accumulator producing company" and UC "Lubny water supply station".

Analyzing frequency and spectrum of visible mutations, variations in the response of various winter wheat varieties on the effect of environmental mutagenic factors were found out. The impact of soil contamination with heavy metals on the territory of SC "Poltavchimmash", where two varieties were grown, caused higher mutagenic effect in variety Al'batros odes'kyi, whereas variety Zymoiarka appeared to be more resistant to mutagenic factors. Genetic variation of the varieties was recorded on a spontaneous mutation level, which was $0.81-0.99 \%$ for Al'batros odes'kyi and $0.77 \%$ for Zymoiarka. A spontaneous mutation level of the variety is interconnected with total mutability induced by mutagens, in most cases there is instant dependence between them [18]. Higher mutability of Al'batros odes'kyi plants is confirmed by wide mutation spectrum which includes 12 types, while variety Zymoiarka, under the same conditions, is characterized by 5 types, some of them were seen in spontaneous mutagenesis. Specificity of variety response and response of individual organisms within one species to the effect of the mutagens with the same vigor and rate was noted by many researchers both on wheat and other crops. However, each of the studied factors of mutagenic process chain (genotype, mutagen) is to be considered not by itself, but in the interaction with other factors of the environment.

The seriousness of the consequences of genetic disorders are confirmed by complex mutations which occurred under the effect of soil contamination with heavy metals of the territories of UC "Lubny water supply station", near B. Khmelnytskyi Street in Kostiantynivka, SC "Poltavchimmash". The following mutations occurred on Zymoiarka winter wheat: late, low-grown, square-headed spike, lack of wax film or yellow peak of a flag leaf; intensive growth, average early, high-grown; high-grown, average early, semi-awned spike; low-grown, short spike; late ripening, spelt awned spike; high-grown, semi-awned spike; long, loose spike. Winter wheat Albatros odeskyi showed forms which could be characterized as high-grown, early ripening, with intensive growth, with short spike; high-grown, with long spike; shortgrown, late ripening, with light-green leaves and long spike; high-grown, with intensive growth, dense spike, antocyanin awns; high-grown, with short spike.

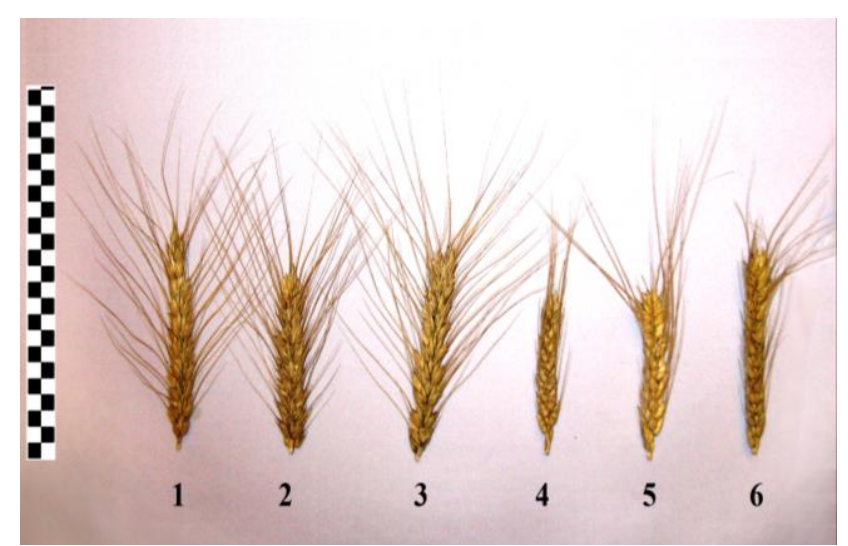

Fig. 1. Mutants according to Al'batros odes'kyi spike morphology: 1 - initial form; 2 - short spike; 3 - cylindrical spike; 4 - dense spike; 5,6- square-headed spike

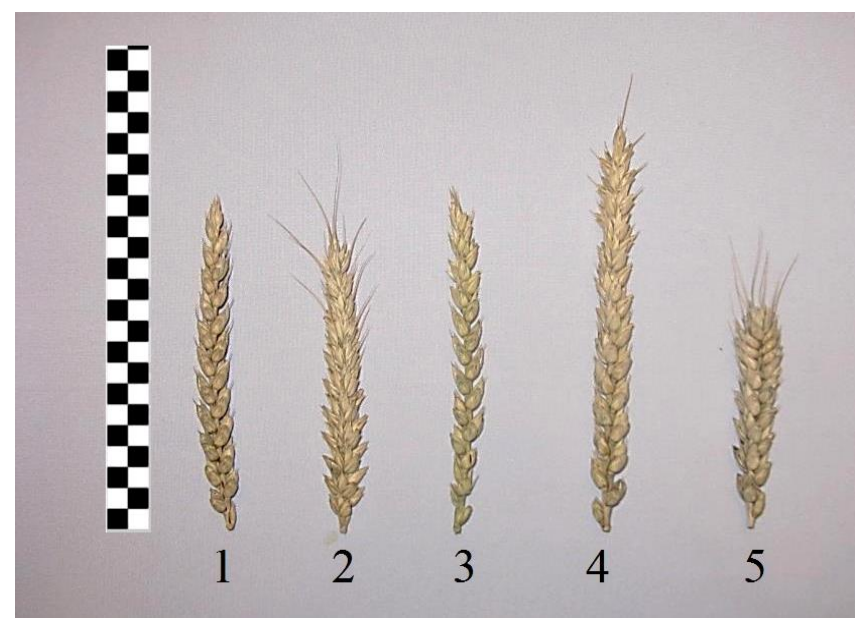

Fig. 2. Mutants according to Zymoiarka spike morphology: 1 - initial form; 2 - semi-awned spike; 3 - loose spike; 4 - long spike; 5 - square-headed spike

\section{Conclusions}

So, soil contamination with heavy metals of industrial discharges causes considerable increase of mutation variability of winter wheat, which exceeds the indicators of spontaneous level by 2.1-4.9 times and can be a genetic threat to living organisms. 4.1-time increase of visible mutation frequency near B. Khmelnytskyi Street (Kostiantynivka) confirms uncontrolled heavy metal contamination of the far-away areas from the industrial zone. Based on the results of studying frequency and spectrum of visible mutation types of winter wheat, it has been found out that the highest mutagen activity is expressed in variety Al'batros odes'kyi in the contaminated areas adjacent to Burshtynska TPS, SC "Poltavchimmash", and near B. Khmelnytskyi Street (Kostiantynivka), UC "Lubny water supply station" and SPC "Specialized company for thermal processing of firm household garbage" Kharkiv city. Spectrum of muta- 
tions includes typical inherited changes: late maturity, high and short, long, dense, loose spike. Besides, some original and rare mutations were seen: wide leaf, lack of wax film, yellow peak of flag leaf, antocyanin spike husk, spike with twisted axis, light-green leaf; they all together with typical mutations can be used as indicators of industrial contamination of the environment with heavy metals.

\section{References}

1. Mamedova, A. O. Bioindication of environmental quality based on plant mutational and modification variability [Text] / A. O. Mamedova // Cytology and genetics. - 2009. - Vol. 43, Issue 2. - P. 123-125. doi: 10.3103/s009545270902008x

2. Vazhenko, O. V. The condition of aerial sphere in Zaporizhia region and zinc content in blood granulocytes of the people who live in the area with high level of atmosphere contamination [Text] / O. V. Vazhenko, Yu. V. Yeshchenko, N. V. Hryhorova et. al. // Problems of ecology and medicine. - 2007. - Vol. 11, Issue 3-4. - P. 21-26.

3. Maistrenko, V. N. Superecotoxicants: myths and reality [Text]: theses / V. N. Maistrenko // Chemical ecology. - Ufa, 2001. - P. 118-127.

4. Serheieva, L. Ye. Heavy metal ions and cell breeding of plants [Text] / L. Ye. Serheieva // Physiology and biochemistry of cultured plants. - 2006. - Vol. 38, Issue 3. - P. 197-208.

5. Maltseva, I. A. The effect of lead and copper excess on soil weeds [Text] / I. A. Maltseva, Yu. P. Adamenko, T. I. Zhohlo et. al. // Ecology and noospherology. - 2008. - Vol. 19, Issue 1-2. - P. 125-128.

6. Serdiuk, A. M. Health of Ukraine's population: the effect of genetic processes [Text] / A. M. Serdiuk, O. I. Tymchenko, V. V. Elagyn // Journal of Ukraine's AMS. - 2007. - Vol. 13, Issue 1. - P. 78-92.

7. Nies, D. H. Microbial heavy-metal resistance [Text] / D. H. Nies // Applied Microbiology and Biotechnology. - 1999. Vol. 51, Issue 6. - P. 730-750. doi: 10.1007/s002530051457

8. Boiko, I. V. Degradation of chlorophyll in the leaves when affected by cadmium and salicylic acid ions [Text] / I. V. Boiko, M. S. Kobyletska, O. I. Terek // Physiology and biochemistry of cultured plants. - 2012. - Vol. 44, Issue 5. - P. 449-456.

9. Zaripova, N. R. Heavy metals differentially regulate the transcription of plastid genes and block mRNA splicing [Text] / N. R. Zaripova, Ya. O. Zubo, A. K. Kravtsov, V. P. Kholodova, V. V. Kuznetsov, V. V. Kusnetsov // Doklady Biological Sciences.2008. - Vol. 423, Issue 2. - P. 395-399. doi: 10.1134/s0012496608060082

10. Al-Yemeni, M. N. Effect of cadmium, mercury and lead on seed germination and early seedlings of Vigna ambacensis L [Text] / M. N. Al-Yemeni // Indian Journal of Plant Physiology. - 2001. - Vol. 6, Issue 2. - P. 147-151.

11. Baccouch, S. Nickel toxicity induces oxidative damage in Zea mays roots [Text] / S. Baccouch, A. Chaoui, E. El Ferjiani // Journal of Plant Nutrition. - 2001. - Vol. 24, Issue 7. - P. 1085-1097. doi: 10.1081/pln-100103805

12. $\mathrm{He}, \mathrm{B} . \mathrm{Pb}$ uptake, accumulation sub-cellular distribution in a Pb-accumulating ecotype of Sedum alfredii (Hance) [Text] / B. He, X. Yang, W. Ni, Y. Wei, H. Ye // Journal of Zhejiang University-SCIENCE A. - 2003. - Vol. 4, Issue 4. - P. 474-479. doi: 10.1631/jzus.2003.0474

13. Kevresan, S. Nitrogen and protein metabolism in young pea plants as affected by different concentrations of nickel, cadmium, lead and molybdenum [Text] / S. Kevresan, N. Petrovic, M. Popovic, J. Kandrac // Journal of Plant Nutrition. - 2001. Vol. 24, Issue 10. - P. 1633-1644. doi: 10.1081/pln-100106026

14. Shvets, L. S. Bioindication of the intensity of the environmental contamination according to fertility indicators of pollen grains of various plants [Text] / L. S. Shvets // Achievements of biology and medicine. - 2011. - Vol. 17, Issue 1. - P. 41-44.

15. Bohuslavska, L. V. Cytogenetic activity of meristem cells of corn roots under separated and joint effect of heavy metal ions [Text] / L. V. Bohuslavska, L. V. Shupranova, O. M. Vinnychenko // Bulletin of Ukrainian association of geneticists and plant breeders. - 2009. - Vol. 7, Issue 1. - P. 10-16.

16. Bodnar, L. S. Monitoring of genetic-toxicological contamination of some environmental factors [Text] / L. S. Bodnar, A. V. Matsiah, V. V. Beliaiev // Genetics and plan breeding in Ukraine on the brink of centuries. - Kyiv: Lohos, 2001. - P. $219-225$.

17. Bittueva, M. M. Efficiency of the prediction of carcinogenic activities of chemical substances based on scoring somatic mutations in the soybean Glycine max (L.) Merrill [Text] / M. M. Bittueva, S. K. Abilev, V. A. Tarasov // Russian Journal of Genetics. - 2007. - Vol. 43, Issue 1. - P. 64-72. doi: 10.1134/s1022795407010103

18. Morgun, V. V. Mutation wheat breeding [Text] / V. V. Morgun, V. F. Logvinenko. - Kyiv: Naukova dumka, 1995. - 627 p.

19. Dospehov, B. A. Methodology of field trial (with principles of statistic processing of research results) [Text] / B. A. Dospehov. - Moscow: Agropromizdat, 1985. - 351 p.

20. Lakin, G. F. Biometrics [Text] / G. F. Lakin. - Moscow: Vysshaia shkola, 1990. - 350 p.

21. Dudnyk, I. M. Ecologic-hygienic problems of transport environmental contamination in Donbas [Text]: theses / I. M. Dudnyk // Urgent issues of hygiene and ecological safety of Ukraine. - 2003. - Issue 5. - P. 122.

\section{Рекомендовано до публікаиії д-р біол. наук Кочь С. Я.} Дата надходження рукопису 20.01.2017

Yakymchuk Ruslan, PhD, associate professor, Department of biology and teaching methods, Pavlo Tychyna Uman state pedagogical university, Sadova str., 2, Uman, Ukraine, 20300

E-mail: peoplenature@ rambler.ru

Sorokina Svitlana, $\mathrm{PhD}$, associate professor, Department of biology and teaching methods, Pavlo Tychyna Uman state pedagogical university, Sadova str., 2, Uman, Ukraine, 20300

E-mail: ssorokina@mail.ru 